\title{
Rat liver pyruvate carboxylase
}

\section{Purification, detection and quantification of apo and holo forms by immuno-blotting and by an enzyme-linked immunosorbent assay}

\author{
Fazal AHMAD, Patricia M. AHMAD and Armando MENDEZ \\ Department of Oncology, Papanicolaou Comprehensive Cancer Center, University of Miami School of Medicine, Box 016188, \\ Miami, FL 33101, U.S.A.
}

\begin{abstract}
A simple scheme for the purification of pyruvate carboxylase from rat liver mitochondria is described. It is rapid and provides high-purity pyruvate carboxylase with excellent yield and reproducibility. The final enzyme preparations appear to be homogeneous by the following criteria: elution behaviour on molecularsizing matrix, SDS/polyacrylamide-gel electrophoresis, Ouchterlony double-diffusion analysis and Western blotting. Detection and quantification of nanogram amounts of pyruvate carboxylase (apo and holo forms) in total tissue homogenates by immuno-blotting and by enzyme-linked immunosorbent assay are described. The data provided suggest that under normal physiological conditions (both in vivo and in vitro) essentially all the pyruvate carboxylase molecules are biotinylated.
\end{abstract}

\section{INTRODUCTION}

Pyruvate carboxylase (EC 6.4.1.1), a biotinyl-metalloenzyme, resides in the mitochondrial matrix of mammalian cells (for reviews see Utter et al., 1975; Barritt et al., 1976; Attwood \& Keech, 1984). It catalyses the synthesis of oxaloacetate from pyruvate as shown below:

$$
\text { Pyruvate }+\mathrm{ATP}+\mathrm{HCO}_{3}{ }^{-} \rightleftharpoons \text { oxaloacetate }+\mathrm{ADP}+\mathrm{P}_{\mathrm{i}}
$$

Pyruvate carboxylase occupies a strategic position in the intermediary metabolism of numerous tissues. In gluconeogenic tissues (e.g. liver, kidney) it catalyses the first step in the synthesis of glucose from pyruvate. During lipogenesis in liver, adipose tissue and mammary gland it participates in the synthesis of acetyl groups and reducing groups for transport from the mitochondria to the cytosol (Ballard \& Hanson, 1967; Utter et al., 1975; Barritt et al., 1976). In yet other tissues (e.g. brain) it fulfils an anaplerotic function (Kornberg, 1966). Because of its importance in the intermediary metabolism of prokaryotes and eukaryotes, pyruvate carboxylase has been investigated in detail with respect to reaction mechanism, subunit structure, relation between structure and activity and regulation of its catalytic activity (Seufert et al., 1971; Scrutton \& Young, 1972; Scrutton \& Fung, 1972; Ashman et al., 1972; Cohen et al., 1978; Goss et al., 1979).

Pyruvate carboxylase exists in an inactive apo form and an enzymically active holo form. Nutritional, hormonal and developmental changes alter pyruvate carboxylase activities in animal tissues and in certain experimental cell lines (Mackall \& Lane, 1977; Weinberg \& Utter, 1980), but the effects of these physiological perturbations on the apo-/holo-enzyme ratios have not been thoroughly studied. Pyruvate carboxylase deficiency in humans causes severe acidosis, which if uncorrected results in death. Administration of pharmacological doses of biotin ameliorates symptoms of acidosis in infants suffering from pyruvate (and/or multiple) carboxylase deficiency- (cies), suggesting that, although apo pyruvate carboxylase may be synthesized normally, its conversion into the enzymically active holo form may not occur in these patients (Nyhan, 1985; Gravel \& Robinson, 1985; Sweetman et al., 1985). Since the presence of catalytically incompetent apo pyruvate carboxylase would engender clinical manifestations similar to those of holo pyruvate carboxylase deficiency, it would be desirable to have available a sensitive and specific method suitable for the detection and quantification of both forms of pyruvate carboxylase in tissue samples or cell extracts. The Western-blot technique described here fulfils this objective. The specific antiserum required for immuno-blotting necessitated purification of pyruvate carboxylase. A brief account of a modified procedure that provides enzyme of high purity with excellent overall recoveries is given below. In addition, an e.l.i.s.a. method for pyruvate carboxylase is described.

\section{MATERIALS AND METHODS}

\section{Materials}

Pyruvate, avidin, biotin, phenylmethanesulphonyl fluoride, bovine serum albumin (essentially fatty acidfree), $p$-nitrophenyl phosphate and dithiothreitol were purchased from Sigma Chemical Co. (St. Louis, MO, U.S.A.). Acetyl-CoA and NADPH were from Pharmacia P-L Biochemicals (Milwaukee, WI, U.S.A.). All reagents for SDS/polyacrylamide-gel electrophoresis, Bio-Gel A-1.5 m (200-400 mesh), Zetaprobe membranes for immunoblot and the affinity-purified goat anti-[rabbit IgG ( $\mathrm{H}$ and $\mathrm{L}$ )] antibody-horseradish peroxidase conjugate were the products of the Bio-Rad Laboratories (Richmond, CA, U.S.A.). Bethesda Research Laboratories (Gaithersberg, MD, U.S.A.) supplied the pre-stained high- $M_{\mathrm{r}}$ protein standards. Cappel Laboratories (West Chester, PA, U.S.A.) was the source for affinity purified goat anti-(rabbit IgG) antibody-alkaline phosphatase conjugate, and the removable Immulon II strips for 
e.l.i.s.a. were obtained from Dynatech Laboratories (Alexandria, VA, U.S.A.). Malate dehydrogenase (EC 1.1.1.37) was purchased from Boehringer Mannheim Biochemicals (Indianapolis, IN, U.S.A.). Trasylol was the product of Calbiochem (San Diego, CA, U.S.A.). All other chemicals were of the highest purity commercially available.

\section{Animals and their maintenance}

Fischer (male and female) rats, maintained on Purina Lab Chow and water ad libitum, were used in all experiments. They were housed in a controlled-temperature environment $\left(22^{\circ} \mathrm{C}\right)$ with a uniform light-cycle (07:00-19:00 $\mathrm{h}$ daily).

\section{T3-L cells}

3T3-L cells obtained from Professor H. Green (Harvard University) were grown in Dulbecco's modified Eagle's medium (Green \& Kehinde, 1974). For uniform and rapid differentiation, confluent cultures were treated with 3-isobutyl-1-methylxanthine and dexamethasone (Russell \& Ho, 1976; Rubin et al., 1978). Accumulation of apo pyruvate carboxylase in differentiated cells was accomplished as described by Freytag \& Utter (1980).

\section{Preparation of avidin (monomer)-Sepharose column}

Avidin (monomer) was covalently coupled to Sepharose (Henrickson et al., 1979). The biotin-binding capacity of the gel varied between 25 and $35 \mathrm{nmol}$ of biotin $/ \mathrm{ml}$ of packed gel (Ahmad \& Ahmad, 1985).

\section{Gel electrophoresis}

SDS/polyacrylamide-gel electrophoresis was carried out by the method of Laemmli (1970).

\section{Antibody production}

Antibodies against rat liver pyruvate carboxylase were produced in rabbits. The immune serum was processed and stored as described previously (Ahmad et al., 1979).

\section{Amino acid analysis}

For amino acid analysis $20-40 \mu \mathrm{g}$ of pyruvate carboxylase was hydrolysed with toluene-p-sulphonic acid containing $0.2 \% 3$-(2-aminoethyl)indole including 3-guanidinoalanine, which served as an internal standard (Liu \& Chang, 1971). The hydrolysis was performed in vacuo for $48 \mathrm{~h}$ at $110^{\circ} \mathrm{C}$, and the hydrolysates were analysed on a Beckman $120 \mathrm{C}$ amino acid analyser (Ahmad et al., 1982).

\section{Enzyme assays}

Pyruvate carboxylase was assayed at $37^{\circ} \mathrm{C}$ by a ${ }^{14} \mathrm{CO}_{2}$-fixation assay (Atkin et al., 1979). The oxaloacetate formed was determined after its conversion into malate by malate dehydrogenase. Water replaced pyruvate in the blank. Assay conditions were selected to give linear reaction rates with respect to protein concentration and time of incubation. One unit of enzyme activity represents synthesis of $1 \mu \mathrm{mol}$ of oxaloacetate $/ \mathrm{min}$, and specific activity is expressed in units $/ \mathrm{mg}$ of protein.

Propionyl-CoA carboxylase (EC 6.4.1.3) was also assayed by a radioisotopic procedure (Lane \& Halenz, 1962).

Protein was determined by the method of Lowry $e t$ al. (1951), with crystalline bovine serum albumin as standard. Protein concentration of pure enzyme prepara- tions was also determined by measuring absorbance at $280 \mathrm{~nm}$ (McClure et al., 1971). Radioactivity was determined in a Searle Analytic mark III scintillation spectrometer.

\section{Western blotting (immunoblotting)}

For construction of a standard curve, different amounts of pure pyruvate carboxylase, denatured and reduced by dissolving them in a solution of $5 \%$ SDS and $200 \mathrm{~mm}$-2-mercaptoethanol, were subjected to SDS/polyacrylamide-gel electrophoresis in $0.75 \mathrm{~mm}$-thick slab gels $(20-25 \mathrm{~mA}$ for $3 \mathrm{~h})$ consisting of stacking $(3.75 \%$ acrylamide) and separating (7\% acrylamide) segments (Laemmli, 1970). Pyruvate carboxylase was then transferred electrophoretically from the slab gel to the Zetaprobe membrane at $0^{\circ} \mathrm{C}$ in a Trans-Blot Cell (Bio-Rad Laboratories). The cell contained $25 \mathrm{~mm}$ Tris/192 mm-glycine buffer, pH 8.3 (Gershoni \& Palade, 1982), and was operated in high-field intensity mode as recommended by the supplier. Complete transfer of pyruvate carboxylase was accomplished in $3.5 \mathrm{~h}$ at $100 \mathrm{~V}$ or in $16 \mathrm{~h}$ at $50 \mathrm{~V}$.

After the transfer, the remaining binding sites on the Zetaprobe membrane were blocked by treatment with Tris-buffered saline $(500 \mathrm{~mm}-\mathrm{NaCl} / 20 \mathrm{~mm}-\mathrm{Tris} / \mathrm{HCl}$ buffer, $\mathrm{pH} 7.5)$ containing $10 \%(\mathrm{w} / \mathrm{v})$ bovine serum albumin for $12 \mathrm{~h}$ at $60^{\circ} \mathrm{C}$. The membrane then was incubated for $2 \mathrm{~h}$ at $37^{\circ} \mathrm{C}$ and overnight at $4{ }^{\circ} \mathrm{C}$ in $24 \mathrm{ml}$ of Tris-buffered saline containing $1 \%$ bovine serum albumin and $100 \mu \mathrm{g}$ of rabbit anti-(rat liver pyruvate carboxylase) antibodies [that fraction of immune serum precipitated at $40 \%$ saturation of $\left.\left(\mathrm{NH}_{4}\right)_{2} \mathrm{SO}_{4}\right] / \mathrm{ml}$. The membrane was transferred to a solution of horseradishperoxidase-conjugated goat anti-(rabbit IgG) antibody (normal dilution 1:500) for $2 \mathrm{~h}$ at $37^{\circ} \mathrm{C}$ and then was immersed in a solution of the substrate, dimethybenzidine $(1 \mathrm{mg} / \mathrm{ml}$ in $50 \mathrm{~mm}$-Tris/HCl buffer, $\mathrm{pH} 7.2)$ and $0.03 \%$ $\mathrm{H}_{2} \mathrm{O}_{2}$. The reaction was allowed to proceed at room temperature for $20 \mathrm{~min}$. The membrane was washed between each step (except after blockage of proteinbinding sites with $10 \%$ bovine serum albumin) for two 10 min periods with $200 \mathrm{ml}$ of Tris-buffered saline at room temperature. The intensity of the bands was measured by a direct scan of the Zetaprobe in an EC model 910 densitometer (E-C Apparatus Corporation, St. Petersburg, FL, U.S.A.). Photocopies of the immunoblots on white bond paper or nitrocellulose sheets also gave satisfactory scans and provided a permanent record.

Detection of apo and holo pyruvate carboxylase in cell lysates

Samples containing apo- and/or holo-enzyme were reduced and denatured (with 2-mercaptoethanol and SDS) and incubated with avidin. Avidin-treated and untreated control samples were analysed by Western blotting as described above.

\section{E.l.i.s.a. for pyruvate carboxylase}

For construction of a standard curve, Immulon-coated wells of plastic micro-titre plates (96-well plates) were coated with purified pyruvate carboxylase dissolved in $15 \mathrm{~mm}$-sodium carbonate/35 mM-bicarbonate buffer, pH 9.6 (1 $\mu \mathrm{g}$ in $150 \mu \mathrm{l}$ of the buffer/well), by incubation overnight at $4{ }^{\circ} \mathrm{C}$. Unoccupied sites were blocked by the addition of $2 \%(\mathrm{w} / \mathrm{v})$ ovalbumin in phosphate-buffered saline $\quad\left(138 \mathrm{~mm}-\mathrm{NaCl} / 2.7 \mathrm{~mm}-\mathrm{KCl} / 1.5 \mathrm{~mm}-\mathrm{KH}_{2} \mathrm{PO}_{4} /\right.$ 
Table 1. Purification of pyruvate carboxylase from rat liver

For experimental details see the text.

\begin{tabular}{|c|c|c|c|c|c|}
\hline Fraction & $\begin{array}{l}\text { Protein } \\
\text { (mg) }\end{array}$ & $\begin{array}{c}\text { Enzyme } \\
\text { activity } \\
\text { (units) }\end{array}$ & $\begin{array}{c}\text { Specific } \\
\text { activity } \\
\text { (units/mg) }\end{array}$ & $\begin{array}{c}\text { Recovery } \\
(\%)\end{array}$ & $\begin{array}{l}\text { Purification } \\
\text { (fold) }\end{array}$ \\
\hline 1. Mitochondrial extract & 8151 & 1400 & 0.17 & 100 & - \\
\hline 2. $\left(\mathrm{NH}_{4}\right)_{2} \mathrm{SO}_{4}$ fractionation & 758 & 1350 & 1.78 & 96 & 10 \\
\hline $\begin{array}{l}\text { 3. Avidin (monomer)- } \\
\text { Sepharose }\end{array}$ & 44.3 & 878 & 19.8 & 65 & 110 \\
\hline $\begin{array}{l}\text { 4. Bio-Gel A-1.5 m column } \\
\text { chromatography }\end{array}$ & 25.8 & 880 & 34.0 & 65 & 188 \\
\hline
\end{tabular}

$7.8 \mathrm{mM}-\mathrm{Na}_{2} \mathrm{HPO}_{4}$ buffer, $\left.\mathrm{pH} 7.4\right)(200 \mu \mathrm{l} /$ well $)$ and incubation for $2 \mathrm{~h}$ at $37^{\circ} \mathrm{C}$. Unbound protein was removed from wells by three washes (each wash was for $2 \mathrm{~min}$ ) with phosphate-buffered saline containing $0.05 \%$ Tween 20 . Coated plates could be stored for 6 months in an air-tight container at $4^{\circ} \mathrm{C}$.

Different amounts of pyruvate carboxylase were added to a series of plastic tubes containing a fixed amount of anti-(pyruvate carboxylase) antibody, and the contents $(0.22 \mathrm{ml})$ were incubated for $2.5 \mathrm{~h}$ at $28^{\circ} \mathrm{C}$. Duplicate portions $(100 \mu l)$ were transferred to wells coated with pyruvate carboxylase and, after shaking for $10 \mathrm{~min}$, the contents were incubated for $30 \mathrm{~min}$ at $37^{\circ} \mathrm{C}$. After three washes with phosphate-buffered saline/Tween 20, secondary antibody-alkaline phosphatase conjugate $(100 \mu \mathrm{l}$ of 1:100 dilution) was added to the wells, the contents were shaken for $10 \mathrm{~min}$ and the incubation was continued for $30 \mathrm{~min}$ at $37^{\circ} \mathrm{C}$. The wells were washed again three times with phosphate-buffered saline/Tween 20 , substrate solution $(200 \mu \mathrm{l}$ of $1 \mathrm{mg} / \mathrm{ml} p$-nitrophenyl phosphate in diethanolamine buffer, $\mathrm{pH}$ 9.8) was added and the reaction was allowed to proceed for $40 \mathrm{~min}$ at $37^{\circ} \mathrm{C}$. Alkaline phosphatase was inactivated by the addition of $50 \mu \mathrm{l}$ of $3 \mathrm{M}-\mathrm{NaOH}$ and the absorbance of each well on the micro-titre plates was read at $410 \mathrm{~nm}$ in a Dynatech Minireader II. Wells containing only substrate and $\mathrm{NaOH}$ served as blank readings. The results of duplicate analyses agreed within $5 \%$.

\section{RESULTS}

\section{Purification of rat liver pyruvate carboxylase}

The initial steps for the purification of pyruvate carboxylase are similar to those described previously (McClure et al., 1971), except that fresh tissue was used for enzyme isolation and all buffers contained $4 \mu \mathrm{M}$ phenylmethanesulphonyl fluoride and 10 kallikreininactivating units of Trasylol $/ \mathrm{ml}$.

Isolation of mitochondria and separation of propionylCoA carboxylase from pyruvate carboxylase. Intact mitochondria were isolated rapidly from fresh livers, washed and then freeze-dried. Pyruvate carboxylase was extracted with $50 \mathrm{~mm}$-potassium phosphate buffer, $\mathrm{pH}$ 7.0, from the mitochondrial powder, the extract was precipitated with $\left(\mathrm{NH}_{4}\right)_{2} \mathrm{SO}_{4}(45 \%$ saturation) and the precipitate was extracted by gentle stirring for $20 \mathrm{~min}$ with $50 \mathrm{~mm}$-potassium phosphate buffer, $\mathrm{pH} 7.0$, containing $\left(\mathrm{NH}_{4}\right)_{2} \mathrm{SO}_{4}(19.6 \mathrm{~g} / 100 \mathrm{ml})$. On centrifugation,
Table 2. Amino acid composition of rat liver pyruvate carboxylase

\begin{tabular}{|c|c|c|c|c|}
\hline \multirow{3}{*}{$\begin{array}{l}\text { Amino } \\
\text { acid }\end{array}$} & \multicolumn{4}{|c|}{$\begin{array}{l}\text { Amino acid composition (mol of } \\
\text { residue } / 100 \text { mol of residues) }\end{array}$} \\
\hline & \multicolumn{3}{|c|}{ Rat liver enzyme } & \multirow{2}{*}{$\begin{array}{c}\text { Chicken liver } \\
\text { enzyme (calc. from } \\
\text { data of Scrutton \& } \\
\text { Utter, 1965) }\end{array}$} \\
\hline & Prep. 1 & Prep. 2 & Prep. 3 & \\
\hline Asx & 9.8 & 9.8 & 9.5 & 9.0 \\
\hline Thr & 4.5 & 4.4 & 4.4 & 4.2 \\
\hline Ser & 4.6 & 4.6 & 4.6 & 4.2 \\
\hline Glx & 12.5 & 12.5 & 12.1 & 8.5 \\
\hline Pro & 6.0 & 6.0 & 6.2 & 2.3 \\
\hline Gly & 8.6 & 8.9 & 8.9 & 10.1 \\
\hline Ala & 9.5 & 9.8 & 9.5 & 12.7 \\
\hline Cys & 1.3 & 1.6 & - & $1.1^{*}$ \\
\hline Val & 9.0 & 9.3 & 8.1 & 9.1 \\
\hline Met & 2.4 & 2.4 & 2.4 & 1.5 \\
\hline Ile & 3.4 & 3.7 & 3.5 & 4.0 \\
\hline Leu & 7.9 & 8.0 & 8.4 & 10.0 \\
\hline Tyr & 3.0 & 2.9 & 3.3 & 4.1 \\
\hline Phe & 4.9 & 4.8 & 4.7 & 5.8 \\
\hline Lys & 5.3 & 5.1 & 5.3 & 3.3 \\
\hline His & 2.8 & 2.5 & 3.0 & 2.5 \\
\hline Trp & - & - & - & 1.0 \\
\hline Arg & 5.8 & 5.6 & 6.2 & 6.5 \\
\hline
\end{tabular}

* Determined after performic acid oxidation as cysteic acid.

most of the propionyl-CoA carboxylase remained in the $30000 \mathrm{~g}$ supernatant and essentially all of the pyruvate carboxylase activity sedimented with the pellet, which was dissolved in a minimal volume of Tris/sucrose buffer (100 mM-Tris/HCl buffer, pH 7.2, containing $0.5 \mathrm{M}$ sucrose, $1 \mathrm{~mm}$-EDTA and $1 \mathrm{~mm}$-dithiothreitol. After quick freezing in a solid- $\mathrm{CO}_{2} /$ acetone bath, this enzyme solution may be stored at $-70^{\circ} \mathrm{C}$ for up to 2 months without any noticeable loss in activity.

Avidin (monomer)-Sepharose affinity chromatography. The enzyme solution (10 $\mathrm{mg}$ of protein $/ \mathrm{ml}$ in Tris/sucrose buffer) from the previous step was pumped through (and recirculated if necessary) the avidin-Sepharose column $(2 \mathrm{~cm} \times 12 \mathrm{~cm})$ at a flow rate of $2-3 \mathrm{ml} / \mathrm{h}$. Essentially all (over $95 \%$ ) of the pyruvate carboxylase activity was retained on the column. The column was washed extensively with the Tris/sucrose buffer to remove unabsorbed protein $\left(A_{280}<0.005\right)$. Pyruvate carboxylase 
(a)

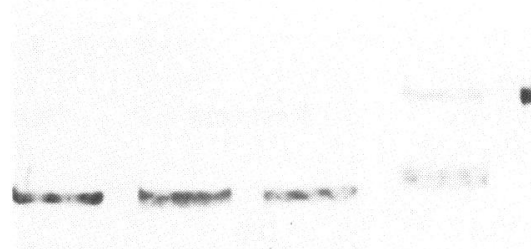

政

\begin{tabular}{|c|c|c|c|c|c|c|c|c|c|}
\hline & & & & & & & Avidin ....- & + & + \\
\hline 1 & 2 & 3 & 4 & 5 & 6 & 7 & & & \\
\hline- & - & - & + & + & - & + & & & \\
\hline
\end{tabular}

Fig. 1. Detection of apo and/or holo forms of pyruvate carboxylase in 3T3-L adipocytes and liver mitochondria

Mitosols derived from biotin-sufficient and biotin-deficient 3T3-L adipocytes and from rat liver were reduced, denatured and incubated with avidin where indicated. Avidin-treated $\left(15 \mathrm{~min}\right.$ at $\left.37^{\circ} \mathrm{C}\right)$ and untreated samples were subjected to immuno-blot analysis as described in the Materials and methods section except that the Zetaprobe membrane was incubated in a solution of the primary antibody for only $2 \mathrm{~h}$. Pre-stained proteins [myosin $\left(M_{\mathrm{r}} 200000\right)$, phosphorylase $b\left(M_{\mathrm{r}} 97000\right)$, bovine serum albumin $\left(M_{\mathrm{r}}\right.$ 68000) and ovalbumin $\left(M_{\mathrm{r}} 43000\right)$ ] were included during each analysis to enable determination of the $M_{\mathrm{r}}$ values of unknown polypeptides. The amounts of protein applied to slab-gel slots are shown in parentheses. (a) Lane 1, pure rat liver pyruvate carboxylase $(250 \mathrm{ng})$; lane 2 , mitosol of biotin-deficient adipocytes $(30 \mu \mathrm{g})$; lane 3 , mitosol of biotin-optimal cells $(30 \mu \mathrm{g})$; lane 4 , mitosol of biotin-deficient cells $(30 \mu \mathrm{g})+$ avidin $(10 \mu \mathrm{g})$; lane 5 , mitosol of biotin-optimal adipocytes $(30 \mu \mathrm{g})+$ avidin $(10 \mu \mathrm{g})$; lane 6 , purified rat liver pyruvate carboxylase $(500 \mathrm{ng})$; lane 7 , purified rat liver pyruvate carboxylase (500 ng) + avidin (1 $\mu \mathrm{g})$. (b) Lane 1, rat liver mitosol (140 $\mu \mathrm{g}=8 \mathrm{munits})$; lane 2, rat liver mitosol (140 $\mu \mathrm{g})+\mathrm{avidin}(250 \mathrm{ng})$; lane 3, rat liver mitosol $(140 \mu \mathrm{g})+$ avidin $(500 \mathrm{ng})$; lane 4, pure rat liver pyruvate carboxylase (100 ng). (a) is a composite of three individual runs. Samples in lanes $1-3,4$ and 5 and 6 and 7 were analysed at different times and the $M_{\mathrm{r}}$ values of the polypeptides were assessed in each case by comparison with a standard curve constructed independently by using proteins of known $M_{\mathrm{r}}$ values. The $M_{\mathrm{r}}$ of the apo and holo pyruvate carboxylase was assessed to be 130000 , and the holoenzyme in combination with avidin migrated with a mobility corresponding to $M_{\mathrm{r}} 180000$.

was then eluted from the column with Tris/sucrose buffer containing $0.2 \mathrm{~mm}$-biotin. At times $100 \%$, but usually $50-70 \%$, of the activity retained on the column is recovered by elution with biotin-containing buffer.

Bio-Gel A-1.5 m colomn chromatography. The enzyme from the avidin column was concentrated by $\left(\mathrm{NH}_{4}\right)_{2} \mathrm{SO}_{4}$ precipitation, the precipitate dissolved in $25 \mathrm{mM}$-potassium phosphate buffer pH 7.5, containing 2 mM-EDTA, $1 \mathrm{~mm}$-dithiothretol and $10 \%(\mathrm{v} / \mathrm{v})$ glycerol and the resulting solution chromatographed on a Bio-Gel A-1.5 m column $(15 \mathrm{~cm} \times 85 \mathrm{~cm})$. Almost all of the enzyme was recovered at a constant specific activity across a symmetrical protein peak. Fractions were pooled and the enzyme was precipitated by the addition of solid $\left(\mathrm{NH}_{4}\right)_{2} \mathrm{SO}_{4}$ to $45 \%$ saturation. The precipitate was dissolved in a minimal volume of $50 \mathrm{~mm}$-potassium phosphate buffer, pH 7.5, containing 2 mM-EDTA, $1 \mathrm{~mm}$-dithiothreitol and $2 \mathrm{M}$-sucrose, and stored in small portions at $-70^{\circ} \mathrm{C}$ as described above. Under these conditions the enzyme retains full catalytic activity for at least 6 months.

A summary of the complete purification scheme for rat liver pyruvate carboxylase is presented in Table 1 .

\section{Purity}

The purity and $M_{\mathrm{r}}$ of the constituent polypeptide(s) of rat liver pyruvate carboxylase were assessed by SDS/polyacrylamide-gel electrophoresis. The purity of the preparations was in excess of $95 \%$. Elution behaviour on Bio-Gel A-1.5 m column together with the electrophoretic mobility of the polypeptide arising from the dissociation (SDS + dithiothreitol) of pyruvate carboxylase compared with those of marker proteins (not shown) suggests that the enzyme consists of four identical polypeptides of $M_{\mathrm{r}}$ $125000-130000$. This is in agreement with the values previously reported for a number of vertebrate carboxylases, including rat liver pyruvate carboxylase (McClure et al., 1971; Barden et al., 1975).

A single connecting precipitin band was observed when anti-(rat liver pyruvate carboxylase) antibodies were immuno-diffused against crude (mitochondrial extract) and highly purified pyruvate carboxylase preparations (results not shown). A high level of purity also was indicated by immuno-blotting (see below).

\section{Amino acid composition}

Three preparations of rat liver pyruvate carboxylase were hydrolysed and their amino acid compositions determined (Table 2). The marked similarity between their compositions indicates that the purification procedure described here is reproducible. The amino acid composition of avian liver pyruvate carboxylase (Scrutton \& Utter 1965) is included in Table 2 and, except for their 
contents of proline, glutamate, alanine and lysine, the compositions of the mammalian and avian hepatic carboxylases appear to be similar.

Protein concentration calculated from amino acid analyses was within $10 \%$ of the values determined by the method of Lowry et al. (1951) or calculated from the absorption of pure enzyme at $280 \mathrm{~nm}$ (McClure et al., 1971).

\section{Detection of apo and holo pyruvate carboxylase in cell lysates}

Biotin binds the avidin tetramer $\left(M_{\mathrm{r}} 68000\right)$ with a $K_{\mathrm{d}}$ of $10^{-15} \mathrm{M}$ (Green \& Toms, 1973). This binding is strong enough to prevent dissociation of the holoenzyme-avidin complex during SDS/polyacrylamide-gel electrophoresis (Lau et al., 1979). Depending on the stoichiometry, species of different $M_{\mathrm{r}}$ values may arise from binding of the protomeric form of holo pyruvate carboxylase (130000- $M_{\mathrm{r}}$ protomer contains one biotin molecule) with the four biotin-binding sites of avidin tetramer. Independent experiments showed that the interaction of the holoenzyme-avidin complex with anti-(pyruvate carboxylase) antibodies was similar to that of the apo and holo pyruvate carboxylases. Thus the formation of a complex with avidin does not appear to interfere with the binding of the polyclonal antibodies to the antigenic determinant(s) against which they are directed, and this was exploited to detect both forms of pyruvate carboxylase in cell lysates and tissue homogenates.

Western blots of mitosols of biotin-deficient (Fig. 1a, lane 2) and biotin-sufficient (Fig. 1a, lane 3) cells show that the adipocyte pyruvate carboxylase has nearly the

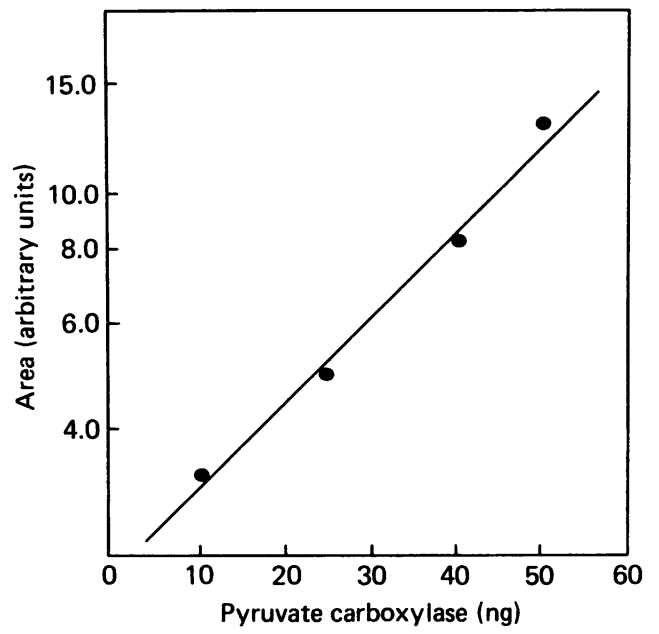

Fig. 2 Construction of a standard curve by immuno-blotting

Different amounts (10-50 ng in $10 \mu \mathrm{l})$ of pure pyruvate carboxylase, after reduction and denaturation, were subjected to SDS/polyacrylamide-gel electrophoresis in $7 \%$ slab gels. Pyruvate carboxylase was transferred electrophoretically from the slab gel to the immobilizing matrix, Zetaprobe membrane, and the Zetaprobe membrane was probed with the primary and secondary antibodies as described in the Materials and methods section. The intensities of the protein bands on the immuno-blots were measured densitometrically, and the electronically integrated areas (in arbitrary units) are plotted against the amount of pyruvate carboxylase applied to the polyacrylamide gel.

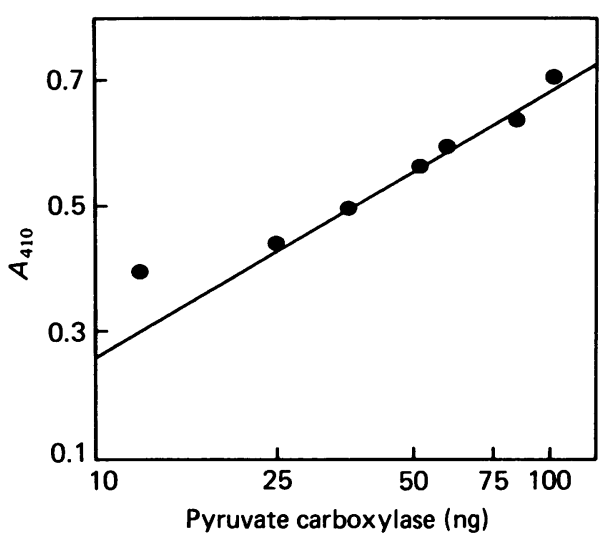

Fig. 3. Construction of a standard curve by e.l.i.s.a.

Differentamounts(10-100 ng) of purepyruvatecarboxylase or portions of appropriately diluted liver homogenates were mixed with a fixed amount $(55 \mu \mathrm{g})$ of anti-(pyruvate carboxylase) antibodies and preincubated (total volume $220 \mu \mathrm{l})$ at $28^{\circ} \mathrm{C}$ for $2.5 \mathrm{~h}$. Portions $(100 \mu \mathrm{l})$ were transferred (in duplicate) to pyruvate carboxylase-coated Immulon wells, shaken for $10 \mathrm{~min}$ and incubated at $37^{\circ} \mathrm{C}$ for $30 \mathrm{~min}$. After three $2 \mathrm{~min}$ washes by immersion in phosphate-buffered saline/Tween 20, the Immulon wells were processed as detailed in the Materials and methods section. The product of the alkaline phosphatase reaction was quantified by measuring $A_{410}$.

same $M_{\mathrm{r}}$ as that of rat liver pyruvate carboxylase (Fig. $1 a$, lane 1). Since the apo- and holo-polypeptides differ in $M_{\mathrm{r}}$ by 244 (the $M_{\mathrm{r}}$ of biotin), this difference in $M_{\mathrm{r}}$ is not sufficient to distinguish between the two forms of the enzyme by SDS/polyacrylamide-gel electrophoresis alone. However, additional experiments showed that most of the pyruvate carboxylase of biotin-deficient cells did not combine with avidin and is therefore predominantly in the apo form with some present as holoenzyme (Fig. 1a, lane 4). This analysis of the mitosolic fraction of biotin-deficient cells is in accord with the low activities measured by the enzymic assays. The biotin-deficient adipocytes contained about $15-20 \%$ of the pyruvate carboxylase activity of biotin-sufficient cells. On the other hand mitosols of differentiated 3T3-L cells maintained on a biotin-sufficient medium contained only holo pyruvate carboxylase, which interacted with avidin (Fig. la, lane 5 ), as did the enzyme from livers of rats fed on normal laboratory chow (Fig. 1b, lanes 2 and 3). In both instances addition of sufficient avidin before SDS/polyacrylamide-gel electrophoresis caused complete removal of the $130000-M_{\mathrm{r}}$ polypeptide (Fig. 1 $a$, lane 5, and Fig. $1 b$, lane 3 ). Therefore, under normal physiological conditions, pyruvate carboxylase molecules appear to be fully biotinylated in the two systems studied (3T3-L adipocytes and rat liver). An analogous situation may exist in other tissues (kidney and brain) that contain significant amounts of pyruvate carboxylase (Utter et al., 1975).

The results of Western-blot analysis also show that anti-(rat liver pyruvate carboxylase) antibodies recognize only the $130000-M_{\mathrm{r}}$ protein component in rat liver mitochondrial lysates (Fig. 1b, lane 1). This observation validates the purity of the antigen used as an immunogen. The molecular size of this component, together with its ability to complex with avidin (Fig. 1b, lanes 2 and 3), 
establishes its identity as the pyruvate carboxylase polypeptide. Thus, when used in conjunction with avidin, the antibodies constitute a highly specific reagent for the detection of the different forms of pyruvate carboxylase in mammalian tissues (rat and mouse).

In order to quantify pyruvate carboxylase protein, a standard curve was constructed by applying different amounts of purified enzyme to a slab gel, which was subjected to SDS/polyacrylamide-gel electrophoresis. The electrophoresed protein was transferred from the gel to a Zetaprobe membrane, which was then probed with anti-(pyruvate carboxylase) antibodies. As shown in Fig. 2 , there is a linear relationship between the amount of purified rat liver pyruvate carboxylase protein applied to the gel and the area under the peak in the densitometric scan over the range $10-50 \mathrm{ng}$.

A comparison of the densitometric scans of lanes 1 and 4 in Fig. $1(b)$ could be used to assess the amount of pyruvate carboxylase protein present in the mitochondrial extract (140 $\mu \mathrm{g}$ of protein contained 8 munits of activity) subjected to immunobotting. The mitosol was found to contain $220 \mathrm{ng}$ of pyruvate carboxylase protein, a value within $10 \%$ of the theoretical amount of $240 \mathrm{ng}$ (calculations based on the specific activity of 30 units/mg of homogeneous pyruvate carboxylase).

\section{E.l.i.s.a. for pyruvate carboxylase}

A standard curve also was constructed by using pure pyruvate carboxylase in the competitive e.l.i.s.a. (Fig. 3). The sensitivity of this procedure is in the same range as that described for Western blotting. A crude mitochondrial extract containing 1.6 units $/ \mathrm{ml}(50 \mu \mathrm{g}$ of pyruvate carboxylase protein $/ \mathrm{ml}$ ) was analysed by the competitive e.l.i.s.a. Two independent determinations gave values of 40 and $48 \mu \mathrm{g} / \mathrm{ml}$ for the amount of pyruvate carboxylase.

\section{DISCUSSION}

Protein blotting has emerged as the method of choice for identifying proteins in complex biological mixtures (for reviews see Towbin \& Gordon, 1984; Gershoni, 1985). Although this method in principle is simple and straightforward, a number of difficulties were encountered in the quantitative transfer of pyruvate carboxylase from polyacrylamide gels to the immobilizing matrix. This is because transfer of high- $M_{\mathrm{r}}$ proteins (the $M_{\mathrm{r}}$ of pyruvate carboxylase polypeptide is 130000 ) from the gel to the immobilizing matrix is considerably less efficient than transfer of low- $M_{\mathrm{r}}$ proteins. In addition, distortions may occur in immuno-blots of high- $M_{\mathrm{r}}$ proteins because of excessive heat production and imperfect contact between the gel and Zetaprobe during the transfer process. This makes assessment of their $M_{\mathrm{r}}$ more difficult. The conditions defined in this paper (current, buffer composition, temperature during protein transfer and nature of the immobilizing matrix) permit an almost quantitative transfer of pyruvate carboxylase from the gel (as determined by silver staining) to the immobilizing matrix, with minimal distortion of its constituent polypeptides (Fig. 1).

Immuno-blotting as described permits identification and the simultaneous quantification of apo and holo forms of pyruvate carboxylase, as shown for 3T3-L adipocytes (Fig. 1a). Obviously this technique is of potential value for analysing clinical samples (containing apo and/or holo pyruvate carboxylase as well as other biotin-containing enzymes) that may be available in limited quantities e.g. tissue biopsies and mammalian cells maintained under defined conditions. In the case of liver, as little as $50-100 \mu \mathrm{g}$ of tissue $(10-20 \mathrm{ng}$ of pyruvate carboxylase protein) would be sufficient for the identification and quantification of pyruvate carboxylase by the immuno-blotting procedure. This estimate is based upon enzyme activities in normal liver of about 10-14 units/g (Weinberg \& Utter, 1980; F. Ahmad, P. M. Ahmad \& A. Mendez, unpublished work), and the specific activity of the apparently homogeneous pyruvate carboxylase preparations ( 30 units $/ \mathrm{mg}$ of protein). This sensitive and specific technique also should prove to be useful in identifying the nature of biological factors (nutrients, hormones or chemicals) that regulate biotinylation of apo pyruvate carboxylase and other biotinrequiring enzymes, especially in experiments performed in vitro.

Both the competitive e.l.i.s.a. and, particularly, Western blotting provide sensitive and specific methods for determining pyruvate carboxylase protein in crude cellular homogenates by means other than those based upon the use of radioisotopes (e.g. radioimmunoassay). E.l.i.s.a. is nearly as sensitive as the immuno-blot procedure. But the latter is superior because it circumvents the difficulties (e.g. those due to non-specific interactions) inherent in the quantification of pyruvate carboxylase protein in cellular extracts and tissue homogenates and permits one to distinguish between the apo and holo forms if present in a given sample under examination. In the immuno-blot method interference due to non-specific interactions is not observed, probably because of the dilution effects (separation during SDS/polyacrylamide-gel electrophoresis) and also because the proteins, once denatured, may no longer combine with the anti-(pyruvate carboxylase) antibodies.

The method described for the purification of pyruvate carboxylase from rat liver mitochondria is rapid and gives excellent overall recoveries (Table 1). It has also been used successfully for the purification of acetyl-CoA carboxylase from rat lactating mammary gland (Ahmad \& Ahmad, 1985). It has the additional advantage over other purification procedures in that our enzyme preparations are nearly homogeneous for the $125000-130000-M_{\mathrm{r}}$ polypeptide (by SDS/polyacrylamide-gel electrophoresis with Coomassie Blue staining and by immuno-blotting) and lack the smaller polypeptides $\left(M_{\mathrm{r}}<130000\right)$ that probably result from proteolytic cleavage in other preparations. Use of fresh tissue and proteolytic inhibitors minimizes proteolysis during enzyme purification. Despite the high level of purity obtained by the scheme described above, there is evidence indicating that even these preparations of pyruvate carboxylase may be contaminated with proteinase activity, albeit small. For example, when reduced and denatured enzyme stored at $4{ }^{\circ} \mathrm{C}$ to $-20^{\circ} \mathrm{C}$ is examined by SDS/polyacrylamide-gel electrophoresis, polypeptides of $M_{\mathrm{r}}<130000$ normally not found in freshly denatured preparations begin to appear and their abundance increases with the duration of storage. In light of these findings it is essential to use freshly denatured enzyme whenever a standard curve by immuno-blotting needs to be constructed.

This work was supported in part by National Institutes of Health, U.S. Public Health Service Grants AM-36739 and CA-15196. We gratefully acknowledge the technical assistance of Janina Blicharaska and Juan Sola. 


\section{REFERENCES}

Ahmad, F. \& Ahmad, P. M. (1985) Ann. N.Y. Acad. Sci. 447, 189-201

Ahmad, P. M., Russell, T. R. \& Ahmad, F. (1979) Biochem. J. 182, 509-514

Ahmad, P. M., Feltman, D. S. \& Ahmad, F. (1982) Biochem. J. 203, 45-50

Ashman, L. K., Keech, D. B., Wallace, J. C. \& Nielsen, J. (1972) J. Biol. Chem. 247, 5818-5824

Atkin, B. M., Utter, M. F. \& Weinberg, M. B. (1979) Pediat. Res. 13, 38-43

Attwood, P. V. \& Keech, D. B. (1984) Curr. Top. Cell. Regul. 23, $1-55$

Ballard, F. J. \& Hanson, R. W. (1967) J. Lipid Res. 8, 73-79

Barden, R. E., Taylor, B. L., Isohashi, F., Frey, W. H., Zander, G., Lee, J. C. \& Utter, M. F. (1975) Proc. Natl. Acad. Sci. U.S.A. 72, 4308-4312

Barritt, G. J., Zander, G. L. \& Utter, M. F. (1976) in Gluconeogenesis (Hanson, R. W. \& Mehlman, M. A., eds.), pp. 1-46, John Wiley and Sons, New York

Cohen, N. D., Beegen, H., Utter, M. F. \& Wrigley, N. G. (1978) J. Biol. Chem. 254, 1740-1747

Freytag, S. O. \& Utter, M. F. (1980) Proc. Natl. Acad. Sci. U.S.A. 77, 1321-1325

Gershoni, J. M. (1985) Trends Biochem. Sci. 10, 103-106

Gershoni, J. M. \& Palade, G. E. (1982) Anal. Biochem. 124, 396- 405

Goss, N. H., Dyer, P. Y., Keech, D. B. \& Wallace, J. C. (1979) J. Biol. Chem. 254, 1734-1739

Gravel, R. A. \& Robinson, B. H. (1985) Ann. N.Y. Acad. Sci. 447, 225-234

Green, H. \& Kehinde, O. (1974) Cell (Cambridge, Mass.) 1, 113-116

Green, N. M. \& Toms, E. J. (1973) Biochem. J. 133, 687-698
Henrickson, K. P., Allen, S. H. G. \& Maloy, W. L. (1979) Anal. Biochem. 94, 366-370

Kornberg, H. L. (1966) Essays Biochem. 2, 1-31

Laemmli, U. K. (1970) Nature (London) 227, 680-685

Lane, M. D. \& Halenz, D. R. (1962) Methods Enzymol. 5, 576-581

Lau, E. P., Cochran, B. C., Munson, L. \& Fall, R. R. (1979) Proc. Natl. Acad. Sci. U.S.A. 76, 214-218

Liu, T. Y. \& Chang, Y. H. (1971) J. Biol. Chem. 246, 2842-2848

Lowry, O. H., Rosebrough, N. J., Farr, A. L. \& Randall, R. J. (1951) J. Biol. Chem. 193, 265-275

Mackall, J. C. \& Lane, M. D. (1977) Biochem. Biophys. Res. Commun. 79, 720-725

McClure, W. R., Lardy, H. A. \& Kneifel, H. P. (1971) J. Biol. Chem. 246, 3569-3578

Nyhan, W. L. (1985) Ann. N.Y. Acad. Sci. 447, 222-224

Rubin, C. S., Hirsch, A., Fung, C. \& Rosen, O. M. (1978) J. Biol. Chem. 253, 7570-7578

Russell, T. R. \& Ho, R.-J. (1976) Proc. Natl. Acad. Sci. U.S.A. 73, 4516-4520

Scrutton, M. C. \& Fung, C. H. (1972) Arch. Biochem. Biophys. 150, 636-647

Scrutton, M. C. \& Utter, M. F. (1965) J. Biol. Chem. 240, 1-9

Scrutton, M. C. \& Young, M. (1972) Enzyme 3rd Edn. 6, 135

Seufert, D., Herlemann, E. V., Albrecht, E. \& Seubert, W. (1971) Hoppe-Seyler's Z. Physiol. Chem 352, 459-478

Sweetman, L., Burri, B. J. \& Nyhan, W. L. (1985) Ann. N.Y. Acad. Sci. 447, 288-296

Towbin, H. \& Gordon, J. (1984) J. Immunol. Methods 72, 313-340

Utter, M. F., Barden, R. E. \& Taylor, B. L. (1975) Adv. Enzymol. Relat. Areas Mol. Biol. 42, 1-72

Weinberg, M. B. \& Utter, M. F. (1980) Biochem. J. 188, 601-608 